\title{
Perubahan kerapatan vegetasi menggunakan citra landsat 8 di kota Batam berbasis web
}

\author{
Sudra Irawan*, Jaheskiel Sirait \\ Program Studi Teknik Geomatika, Politeknik Negeri Batam \\ *Corresponding author email: sudra@polibatam.ac.id
}

Submitted: 08 Maret 2017 / Revised: 18 Desember 2017 / Accepted: 22 Desember 2017

http://dx.doi.org/10.21107/jk.v10i2.2685

\begin{abstract}
The density of vegetation in urban areas and in rural have very little perceived by the public. Information on the density of vegetation is very important to know because of the issue of global warming. This study aims to identify and produce maps of vegetation density in Batam web-based multitemporal time in 2013 and 2016 covering the vegetation density with a value of NDVI (Normalized Difference Vegetation Index) and its range in Batam in 2013 and 2016 and its amendments. The processing of data using transformation NDVI formula Sturgess classified into 5 classes, namely not vegetated, low, medium, tightly, and very tight. Data analysis technique used is the overlay method and descriptive analysis method. Results from the study will be used as web resources related to changes in vegetation density in Batam. Changes in the density of vegetation and its range in Batam in 2013 and 2016, namely, do not have a change vegetated area of 7600.9 hectares with a percentage of $29.3 \%$, lower had a change of total area of 798 hectares with a percentage of $3.1 \%$, while have a change of total area of 3,999 hectares with a percentage of $15.4 \%$, the tightly had a change of total area of 11006.8 hectares with a percentage of $42.5 \%$, and so the tightly had a change of total area of 2508.6 hectares with a percentage of $9.7 \%$.
\end{abstract}

Keyword: Density of Vegetation, NDVI, Landsat 8 imagery, Web.

\begin{abstract}
ABSTRAK
Kerapatan vegetasi di perkotaan dan pendesaan sudah sangat sedikit yang dirasakan oleh masyarakat. Informasi mengenai kerapatan vegetasi ini sangat penting diketahui dikarenakan adanya isu pemanasan global. Penelitian ini bertujuan untuk mengetahui dan menghasilkan peta kerapatan vegetasi di Kota Batam berbasis web secara multitemporal waktu tahun 2013 dan 2016 yang meliputi kerapatan vegetasi dengan nilai NDVI (Normalized Difference Vegetation Index) dan luasannya di Kota Batam tahun 2013 dan 2016 serta perubahannya. Proses pengolahan data menggunakan transformasi NDVI dengan rumus Sturgess yang diklasifikasikan menjadi 5 kelas, yaitu tak bervegetasi, rendah, sedang, rapat, dan sangat rapat. Teknik analisis data yang digunakan adalah metode overlay dan metode analisis secara deskriptif. Hasil penelitian berupa web yang dijadikan sumber informasi terkait perubahan kerapatan vegetasi di Kota Batam. Perubahan tingkat kerapatan vegetasi dan luasannya di Kota Batam tahun 2013 dan 2016 yaitu, tak bervegetasi memiliki perubahan luas area sebesar 7.600,9 hektar dengan persentase 29,3\%, rendah memiliki perubahan luas area sebesar 798 hektar dengan persentase 3,1\%, sedang memiliki perubahan luas area sebesar 3.999 hektar dengan persentase 15,4\%, rapat memiliki perubahan luas area sebesar 11.006,8 hektar dengan persentase $42,5 \%$, dan sangat rapat memiliki perubahan luas area sebesar 2.508,6 hektar dengan persentase 9,7\%.
\end{abstract}

Kata Kunci: Kerapatan Vegetasi, NDVI, Citra Landsat 8, Web.

\section{PENDAHULUAN}

Kota Batam merupakan bagian Provinsi Kepulauan Riau yang memiliki luas wilayah daratan seluas $1.040 \mathrm{~km}^{2}$ atau sekitar 1,5 kali dari wilayah Singapura, sedangkan luas wilayah keseluruhan mencapai $2.950 \mathrm{~km}^{2}$. Kota Batam beriklim tropis dengan suhu rata-rata $26^{\circ} \mathrm{C}$ sampai dengan $34^{\circ} \mathrm{C}$. Kota ini memiliki dataran yang berbukit dan berlembah. 
Pertumbuhan penduduk dan pembangunan kawasan pemukiman dan industri yang pesat tentu berpengaruh cukup besar terhadap penggunaan lahan. Perubahan penggunaan lahan yang tidak sesuai dengan kaidah-kaidah rencana tata ruang dapat mengakibatkan menurunnya kualitas lingkungan, degradasi lingkungan/kerusakan lingkungan serta berkurangnya sumber daya alam. Semakin terdesaknya alokasi ruang untuk vegetasi di perkotaan menyebabkan kualitas lingkungan menurun (Irwan, 2008). Vegetasi mempunyai banyak manfaat baik di pedesaan maupun di perkotaan, yaitu vegetasi dapat mempengaruhi udara di sekitarnya baik secara langsung maupun tidak langsung dengan cara merubah kondisi atmosfer lingkungan sekitarnya. Vegetasi sebagai penyusun lahan mempunyai jenis yang sangat beranekaragam. Kumpulan dari berbagai vegetasi yang beranekaragam ini akan menghasilkan tingkat kerapatan vegetasi yang berbeda-beda pada tiap penggunaan lahan di suatu daerah.

Struktur vegetasi harus diklasifikasi terlebih dahulu dalam rangka melaksanakan suatu manajemen yang layak berdasarkan prinsip kelestarian (Kusmana, 1993). Menurut Spies \& Tunner (1999), manajemen dinamika suatu landscap harus didasarkan pada proses-proses vegetasi yang menjadi dasar dari prosesproses ekologi yang berlangsung pada suatu ekosistem. Penggunaan lahan dengan kerapatan vegetasi yang bermacam-macam dijumpai di Kota Batam. Dalam penelitian Anargi (2008), klasifikasi penggunaan lahan didasarkan pada penyederhanaan dari klasifikasi United State Geological Survey (USGS) tingkat I yang dapat dibedakan ke dalam penggunaan lahan terbangun dan tidak terbangun. Klasifikasi terbangun meliputi pemukiman, industri, pasar, lapangan olahraga, sedangkan pengunaan lahan tidak terbangun yang terdiri dari hutan, kebun, sawah, dan tegalan. Klasifikasi tersebut akan memudahkan dalam mengetahui penggunaan lahan yang mempunyai kerapatan vegetasi tidak rapat hingga sangat rapat di Kota Batam. Kerapatan vegetasi di Kota Batam pada tahun 2013 terlihat baik dikarenakan masih asrinya kondisi perkotaan dan masih banyaknya pepohonan yang dijumpai dalam setiap daerahnya.

Indeks vegetasi yang digunakan untuk mengetahui kerapatan vegetasi yaitu nilai NDVI (Normalized Difference Vegetation Index). NDVI merupakan suatu transformasi untuk menonjolkan aspek vegetasi sehingga dapat menunjukkan tingkat kerapatan vegetasi yang ada di lapangan. Nilai NDVI berkisar antara -1 sampai dengan 1. Semakin besar nilai NDVI menunjukkan semakin tinggi kerapatan vegetasinya. Hasil dari transformasi NDVI ini yaitu citra distribusi indeks NDVI. Metode ini digunakan Widayati (2015) untuk mengetahui perubahan tutupan lahan yang substansial di Kabupaten Nunukan antara tahun 1996-2003 diperkirakan $3,85 \%$ areal hutan primer dikonversi menjadi tipe penggunaan lahan lain setiap tahunnya. Transfromasi NDVI juga merupakan transformasi yang paling efektif digunakan untuk monitoring kondisi dan kerapatan mangrove Rhizophora (Faizal, 2002). Nursal (2015) menggunakan metode ini untuk mengidentifikasi vegetasi di Kabupaten Bengkalis, Provinsi Riau.

Informasi data kerapatan vegetasi, luas lahan, dan keadaan di lapangan dapat dideteksi dari teknik penginderaan jauh (Aftriana, 2013). Salah satu metode perubahan kerapatan vegetasi ini dapat dipantau menggunakan citra Landsat 8 (Iskandar, 2012). Dalam melakukan pemantauan perubahan vegetasi digunakan citra satelit secara multitemporal untuk mengetahui perkembangannya. Citra Landsat 8 adalah generasi terbaru menggantikan Landsat 7 yang memiliki sensor Onboard Operational Land Imager (OLI) dan Thermal Infrared Sensor (TIRS) dengan jumlah kanal sebanyak 11 dengan kanal 1 sampai 9 berada pada OLI dan kanal 10, 11 pada kanal TIRS. Data citra Landsat 8 memiliki resolusi spasial 30 m untuk kanal 1 sampai 9, sedangkan kanal panchromatic memiliki resolusi spasial $15 \mathrm{~m}$. Selain beresolusi spasial $30 \mathrm{~m}$ dan $15 \mathrm{~m}$, pada kanal 10 dan 11 yang merupakan kanal TIR-1 dan TIR-2 memiliki resolusi spasial $100 \mathrm{~m}$. Kelebihan data Landsat 8 adalah adanya kanal Near Infra Red (NIR-Kanal 5) sehingga dengan menggunakan kombinasi RGB yang tepat akan menunjukkan lokasi tanaman mangrove. (Sukristiyanti, 2008).

Berdasarkan hal tersebut, perlu dilakukan penelitian untuk menganalisis perubahan kerapatan vegetasi yang ada di Kota Batam. Pemilihan Kota Batam sebagai lokasi penelitian karena belum adanya penelitian terkait kerapatan vegetasi. Harapannya penelitian ini dapat membantu pemerintah, masyarakat, dan peneliti-peneliti selanjutnya sebagai data pendukung untuk pengendalian alih fungsi lahan dalam rangka mempertahankan tata ruang yang tetap memberikan kenyamanan 


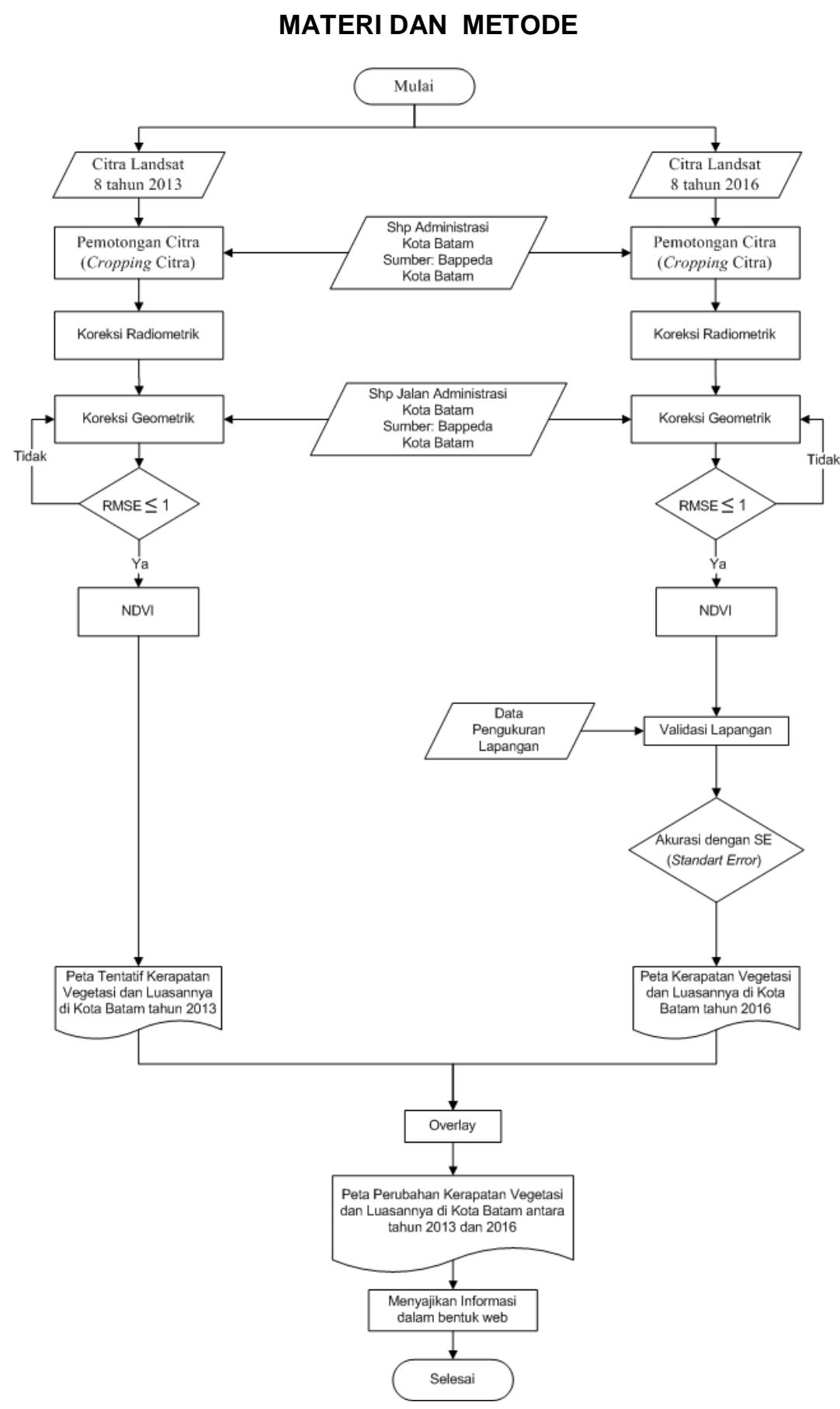

Gambar 1. Tahapan Penelitian

Tahapan penelitian disajikan pada Gambar 1. Penelitian dimulai dengan pengumpulan data. Adapun data yang dipakai dalam penelitian ini yaitu data citra landsat 8 perekaman tahun 2013 dan 2016 yang dapat diunduh di http://earthexplorer.usgs.gov/. Kemudian, dilakukan pemotongan citra menggunakan shp Administrasi Kota Batam yang diperoleh dari BAPPEDA Kota Batam. Pemotongan citra dilakukan untuk memilih daerah penelitian yang akan dilakukan. Citra Landsat 8 hasil perekaman satelit masih perlu dilakukan koreksi radiometrik dan geometrik. Koreksi radiometrik dilakukan untuk memperbaiki kualitas pada citra dan koreksi geometrik dilakukan untuk memposisikan hasil citra ke dalam koordinat UTM (Universal Transverse Mercator). Selanjutnya, dilakukan transformasi NDVI (Normalized Difference Vegetation Index) untuk mendapatkan nilai dari kerapatan vegetasi berdasarkan algoritma NDVI (Yeni, 2011). Setelah didapatkan nilai dari transformasi NDVI, perlu dilakukan validasi untuk menilai seberapa besar kesamaan hasil 
pengolahan data menggunakan transformasi NDVI dengan data di lapangan. Validasi lapangan dilakukan dengan metode akurasi SE (Standart Error). Setelah itu, perhitungan akurasi dimasukkan ke dalam Band Math untuk mendapatkan hasil peta kerapatan vegetasi tahun 2016. Peta tentatif tingkat kerapatan vegetasi tahun 2013 dilakukan overlay dengan peta tingkat kerapatan vegetasi tahun 2016 . Selanjutnya, dilakukan calculate geometry untuk mendapatkan luasannya pada ArcMap, kemudian membuat layout peta. Hasilnya ditampilkan dalam bentuk web
Kerapan vegetasi dibagi menjadi 4 kelas yaitu tak bervegetas, rendahm sedang, rapat, dan sangat rapat untuk masing-masing tahun 2013 dan 2016. Kerapatan vegetasi yang dihasilkan dapat diketahui nilai kebenarannya setelah dilakukan proses pengujian akurasi melalui perhitungan ataupun pengukuran langsung di lapangan (Danoedoro, 2012). Kerapatan vegetasi ini dapat dilakukan dengan jumlah tegakan jenis $i$ dalam suatu unit area, yang perhitungannya menurut Bengen (2000).

$$
D i=\frac{n(i)}{A\left(i n d / m^{2}\right)}
$$

dengan:

Di $\quad=$ kerapatan jenis $i$

$n(i) \quad=$ jumlah tegakan dari jenis $i$

$A\left(\right.$ ind $\left./ \mathrm{m}^{2}\right) \quad=$ luas total area pengambilan sampel (kelas) atau (satuan/piksel)

Data hasil uji akurasi di lapangan kemudian diolah dengan analisis korelasi regresi. Menurut Riduwan (2011) analisis korelasi adalah uji hubungan antara dua variabel atau lebih yang digunakan untuk mengetahui derajat hubungan dan kontribusi variabel bebas terhadap variabel terikat (misalnya $X$ dan $Y$ ). Analisis regresi dilakukan untuk mengestimasi nilai dari suatu variabel berdasarkan nilai variabel lainnya, yaitu suatu variabel terikat (dependent variable) atau $Y$ berdasarkan suatu variabel bebas (independent variable) atau $X$ dalam persamaan linear (Sunardi, 2009). Ukuran kekuatan pengaruh suatu variabel ditentukan dengan menggunakan besarnya nilai koefisien korelasi $(r)$ dan koefisien determinasi $\left(r^{2}\right)$. Koefisien korelasi dicari dengan rumus (Suharsimi, 2002):

$$
r=\frac{\left(n \sum x i y i\right)-\left(\sum x i\right)\left(\sum y i\right)}{\sqrt{\left.\left.\left[\left(\left(n \sum x i^{2}\right)-\sum x i^{2}\right)\right)\left(\left(n \sum y i^{2}\right)-\sum y i^{2}\right)\right)\right]}}
$$

Formula regresi disajikan pada Persamaan 3 (Suharsimi, 2002):

$$
y=a x^{b}
$$

Koefisien a dan b ditentukan dengan cara (Suharsimi, 2002) :

$$
\begin{aligned}
& \log a=\frac{\left(\sum \log y i\right)}{n}-b \frac{\left(\sum \log x i\right)}{n} \\
& b=\frac{n\left(\sum \log x i \log y i\right)-\left(\sum \log x i \log y i\right)}{\left.n\left(\sum \log ^{2} x i\right)-\sum \log ^{2} y i\right)}
\end{aligned}
$$

$n \quad$ = besarnya populasi sampel

$x \quad=$ variabel bebas, yaitu citra NDVI (data citra)

$y \quad=$ variabel terikat, yaitu cek lapangan (data lapangan)

Analisis korelasi digunakan sebagai ukuran tingkat keeratan hubungan antara variabel. Pada penelitian ini variabel yang digunakan adalah nilai Citra NDVI dan nilai pengukuran lapangan. Analisis regresi digunakan untuk menghasilkan persamaan nilai Citra NDVI dan hasil pengukuran lapangan. Hasil dari penelitian ini nantinya akan memberikan informasi mengenai perubahan kerapatan vegetasi di Kota Batam pada tahun 2013 dan 2016 yang disajikan dalam web yang dapat diakses oleh masyarakat. 


\section{HASIL DAN PEMBAHASAN}

\section{Peta Tentatif Tingkat Kerapatan Vegetasi dan Luasannya di Kota Batam tahun 2013}

Peta tentatif tingkat kerapatan vegetasi dan luasannya di Kota Batam tahun 2013 dapat dilihat pada Gambar 2. Tingkat kerapatan vegetasi didapat dari perhitungan algoritma NDVI menggunakan ENVI 4.6.1 dengan menggunakan band 5 dan band 4 citra Landsat 8. Berdasarkan Gambar 2 dapat dilihat bahwa untuk Pulau Batam tingkat kerapatan vegetasi tergolong rendah yaitu kecamatan Belakang Padang dan Kecamatan Bulang, sedangkan untuk Kecamatan Galang kerapatan vegetasi masih tergolong rapat. Hal ini disebabkan pada kecamatan Galang belum ada alih fungsi lahan menjadi pemukiman penduduk. Nilai kerapatan dan presentase indeks vegetasi pada tahun 2013 dapat dilihat pada Tabel 1 .

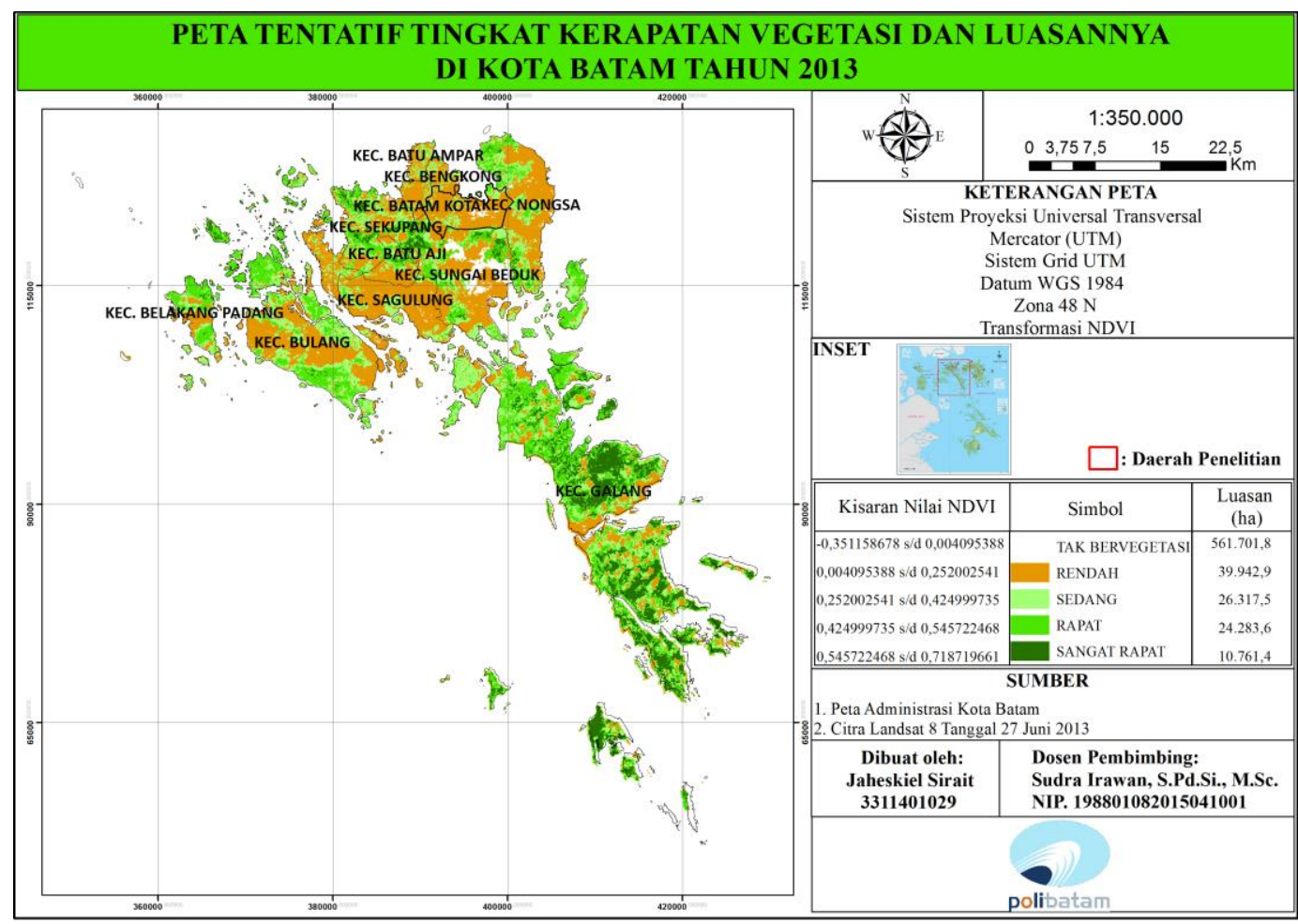

Gambar 2. Peta Tentatif Tingkat Kerapatan Vegetasi dan Luasannya di Kota Batam Tahun 2013

Tabel 1. Tingkat Kerapatan Vegetasi dan Luasnya Tahun 2013

\begin{tabular}{cccccc}
\hline No & $\begin{array}{c}\text { Tingkat } \\
\text { Kerapatan }\end{array}$ & Nilai NDVI & Warna & $\begin{array}{c}\text { Luasannya } \\
\text { (ha) }\end{array}$ & $\begin{array}{c}\text { Persentase } \\
\text { (\%) }\end{array}$ \\
\hline 1 & $\begin{array}{c}\text { Tak } \\
\text { Bervegetasi }\end{array}$ & $-0,351158678$ s.d 0,004095388 & Putih & $561.701,8$ & 84,7 \\
2 & Rendah & 0,004095388 s.d 0,252002541 & Orange & $39.942,9$ & 6 \\
3 & Sedang & 0,252002541 s.d 0,424999735 & Hijau & $26.317,5$ & 4 \\
4 & Rapat & 0,424999735 s.d 0,545722468 & Hijau Muda & $24.283,6$ & 3,7 \\
5 & $\begin{array}{c}\text { Sangat } \\
\text { Rapat }\end{array}$ & 0,545722468 s.d 0,718719661 & Hijau Tua & $10.761,4$ & 1,6 \\
& \multirow{2}{*}{ TOTAL } & & $\mathbf{6 6 3 . 0 0 7 , 2}$ & $\mathbf{1 0 0}$ \\
\hline
\end{tabular}

Penjabaran dari hasil Tabel 1, dihasilkanlah grafik tingkat kerapatan vegetasi dan luasannya di Kota Batam tahun 2013, terlihat bahwa sebesar $84,7 \%$ tingkat kerapatan vegetasi di Kota Batam tergolong tidak 
bervegetasi, artinya tidak ada tumbuhtumbuhan yang hidup di wilayah ini.

\section{Peta Tingkat Kerapatan Vegetasi di Kota Batam Tahun 2016}

Peta tentatif tingkat kerapatan vegetasi dan luasannya di Kota Batam tahun 2016 dapat dilihat pada Gambar 4. Tingkat kerapatan vegetasi didapat dari perhitungan algoritma NDVI menggunakan ENVI 4.6.1 dengan menggunakan band 5 dan band 4 citra Landsat 8. Berdasarkan Gambar 4 dapat dilihat bahwa untuk Pulau Batam tingkat kerapatan vegetasi tergolong rendah, sedangkan kecamatan Belakang Padang dan Kecamatan Bulang mengalami perubahan dari kerapatan kategori rapat pada tahun 2013 menjadi dominasi kerapatan sedang pada tahun 2016. Untuk Kecamatan Galang kerapatan vegetasi mengalami perubahan kerapatan dari dominasi rapat pada tahun 2013 menjadi dominasi sedang pada tahun 2016. Hal ini disebabkan pada kecamatan Galang mulai ada alih fungsi lahan menjadi pemukiman penduduk termasuk fasilitas perkantoran dan wisata. Untuk nilai kerapatan dan presentase indeks vegetasi tahun 2016 dapat dilihat pada Tabel 2.

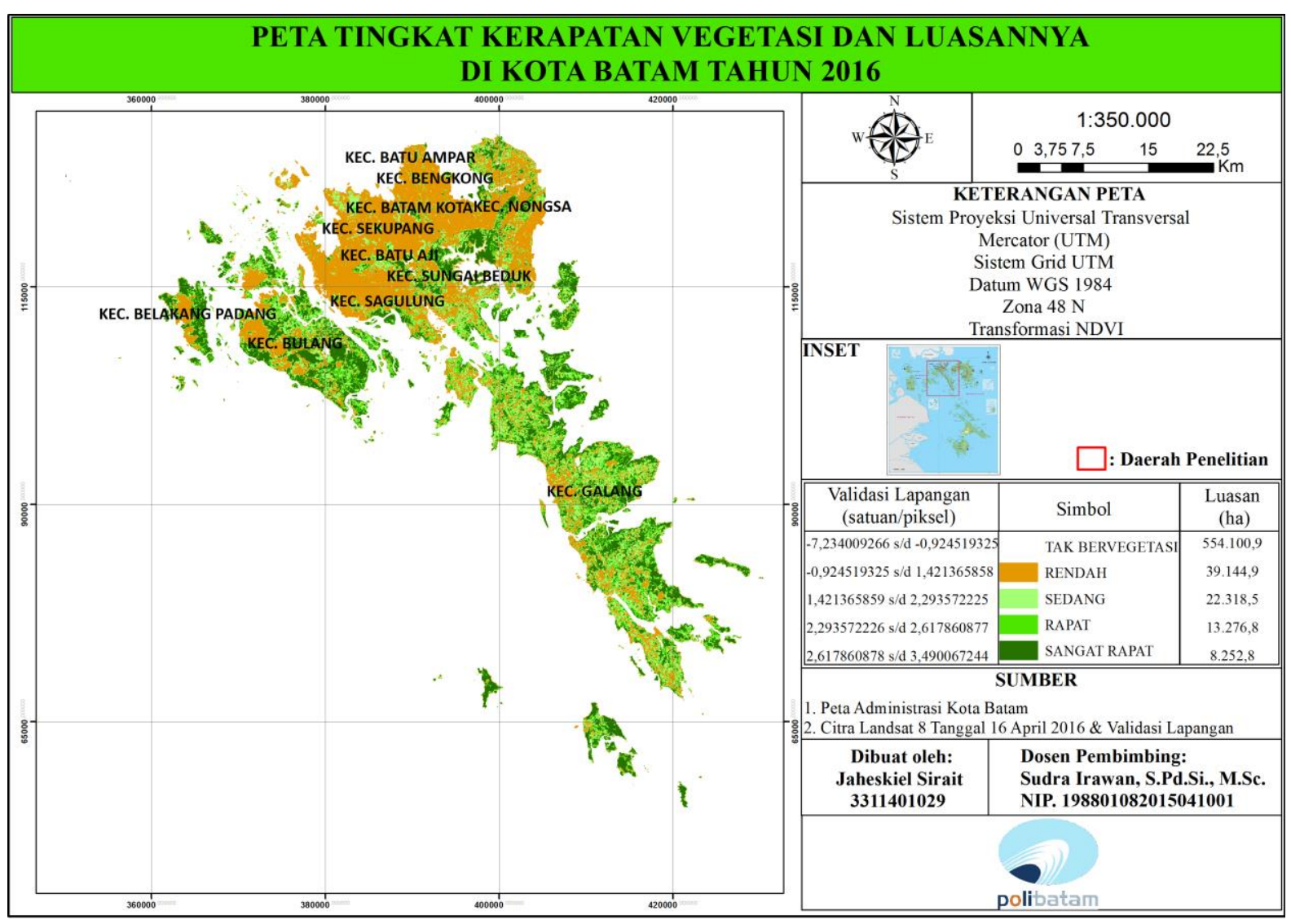

Gambar 3. Peta Tingkat Kerapatan Vegetasi dan Luasannya di Kota Batam Tahun 2016

Tabel 2. Tingkat Kerapatan Vegetasi dan Luasnya Tahun 2016

\begin{tabular}{cccccc}
\hline No & $\begin{array}{c}\text { Tingkat } \\
\text { Kerapatan }\end{array}$ & $\begin{array}{c}\text { Pengukuran Lapangan } \\
\text { (satuan/piksel) }\end{array}$ & Warna & $\begin{array}{c}\text { Luasannya } \\
\text { (ha) }\end{array}$ & $\begin{array}{c}\text { Persentase } \\
\text { (\%) }\end{array}$ \\
\hline 1 & $\begin{array}{c}\text { Tak } \\
\text { Bervegetasi }\end{array}$ & $-7,234009266$ s.d -0,924519325 & Putih & $554.100,9$ & 87 \\
2 & Rendah & $-0,924519325$ s.d 1,421365858 & Orange & $39.144,9$ & 6,1 \\
3 & Sedang & 1,421365859 s.d 2,293572225 & Hijau & $22.318,5$ & 3,5 \\
4 & Rapat & 2,293572226 s.d 2,617860877 & $\begin{array}{c}\text { Hijau } \\
\text { Muda }\end{array}$ & $13.276,8$ & 2,1
\end{tabular}




$\begin{array}{ccccc}5 \text { Sangat Rapat } & 2,617860878 \text { s.d 3,490067244 } & \begin{array}{c}\text { Hijau } \\ \text { Tua }\end{array} & 8.252,8 & 1,3 \\ \text { TOTAL } & & \mathbf{6 3 7 . 0 9 3 , 9} & \mathbf{1 0 0}\end{array}$

Penjabaran dari hasil Tabel 2, dihasilkanlah grafik tingkat kerapatan vegetasi dan luasannya di Kota Batam tahun 2016.

Berdasarkan Gambar 5 terlihat bahwa sebesar $87 \%$ tingkat kerapatan vegetasi di Kota Batam tergolong tidak bervegetasi, meningkat dibandingkan tahun 2013 sebesar 84,7\%. Hasil analisis korelasi antara nilai Citra NDVI dan nilai pengukuran lapangan yang dapat dilihat pada Gambar 6. Berdasarkan hasil perhitungan diperoleh persamaan regresi $y=5,032 x-$ 0,9251 dengan nilai koefisien determinasi $\left(r^{2}\right)$ sebesar 0,6766 yang menunjukkan hubungannya kuat (Suharsimi, 2002), artinya antara nilai Citra NDVI dan nilai pengukuran lapangan menunjukkan nilai yang sama. Kedua nilai bisa sama disebabkan beberapa faktor karena kondisi kerapatan vegetasi pada bulan April dan November mempunyai kesamaan sehingga tidak mempunyai perbedaan antara nilai Citra NDVI dengan nilai hasil pengukuran di lapangan. Selain itu, waktu perekaman data dan pengambilan validasi lapangan tidak terlalu jauh yaitu data citra bulan April 2016, dengan data lapangan diambil pada bulan November 2016.

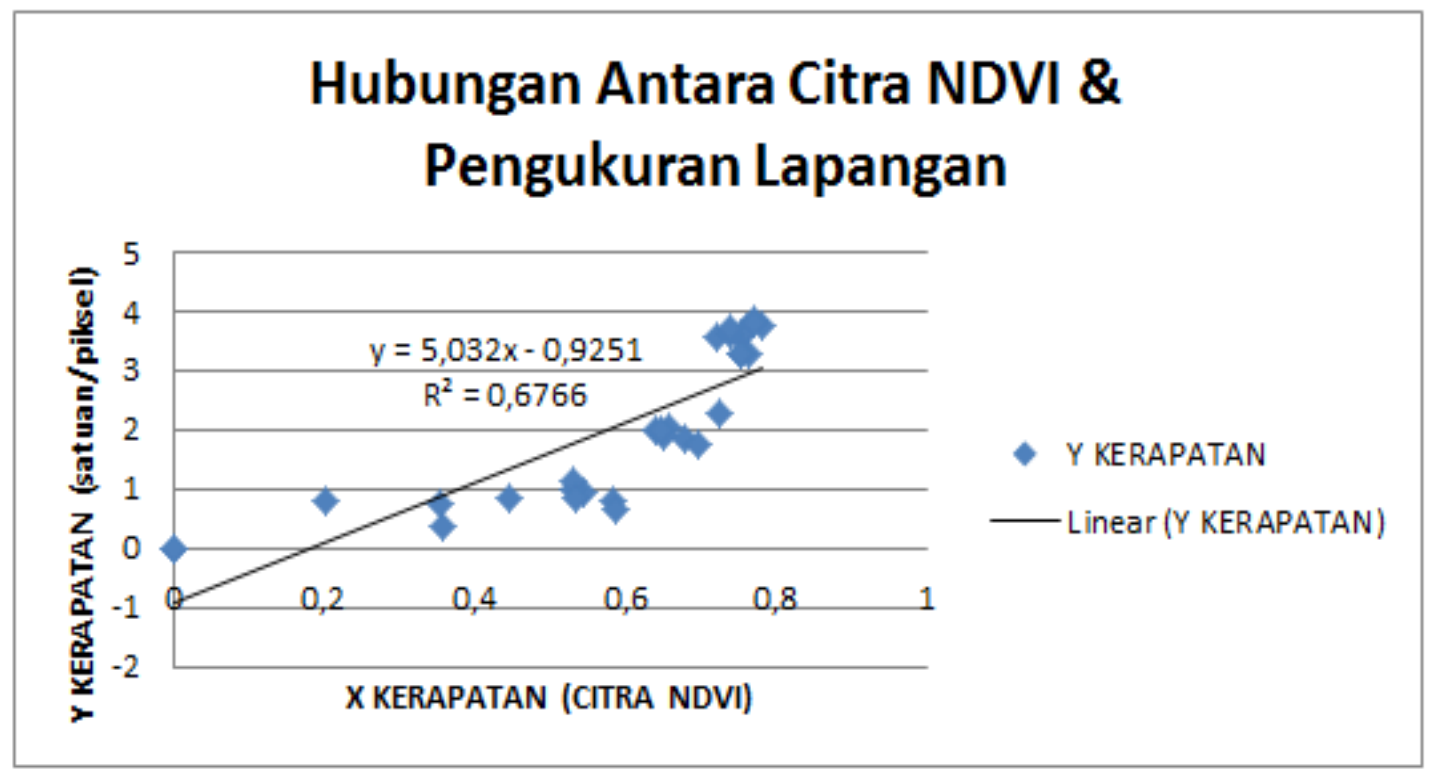

Gambar 4. Analisis Korelasi Regresi Citra NDVI \& Validasi Lapangan

\section{Peta Perubahan Tingkat Kerapatan Vegetasi di Kota Batam Tahun 2013 dan 2016}

Perubahan tingkat kerapatan vegetasi dan luasannya pada tahun 2013 dan 2016 telah dilakukan overlay seperti pada Gambar 7. Peta tersebut menunjukkan perubahan tingkat kerapatan vegetasi dan luasannya di kecamatan yang ada pada Kota Batam. Terlihat bahwa terdapat perubahan kerapatan vegetasi di beberapa kecamatan seperti pada Kecamatan Galang, Kecamatan Bulang,
Kecamatan Belakang Padang, dan Kecamatan Nongsa. Adapun perbandingan kerapatan vegetasi dan luasannya di Kota Batam antara tahun 2013 dan 2016 cukup signifikan. Informasi mengenai perubahan kerapatan vegetasi dan luasannya dapat dilihat pada Tabel 3 dengan jumlah luasan yang telah berubah dalam satuan hektar dan diketahui persentase perubahannya. 


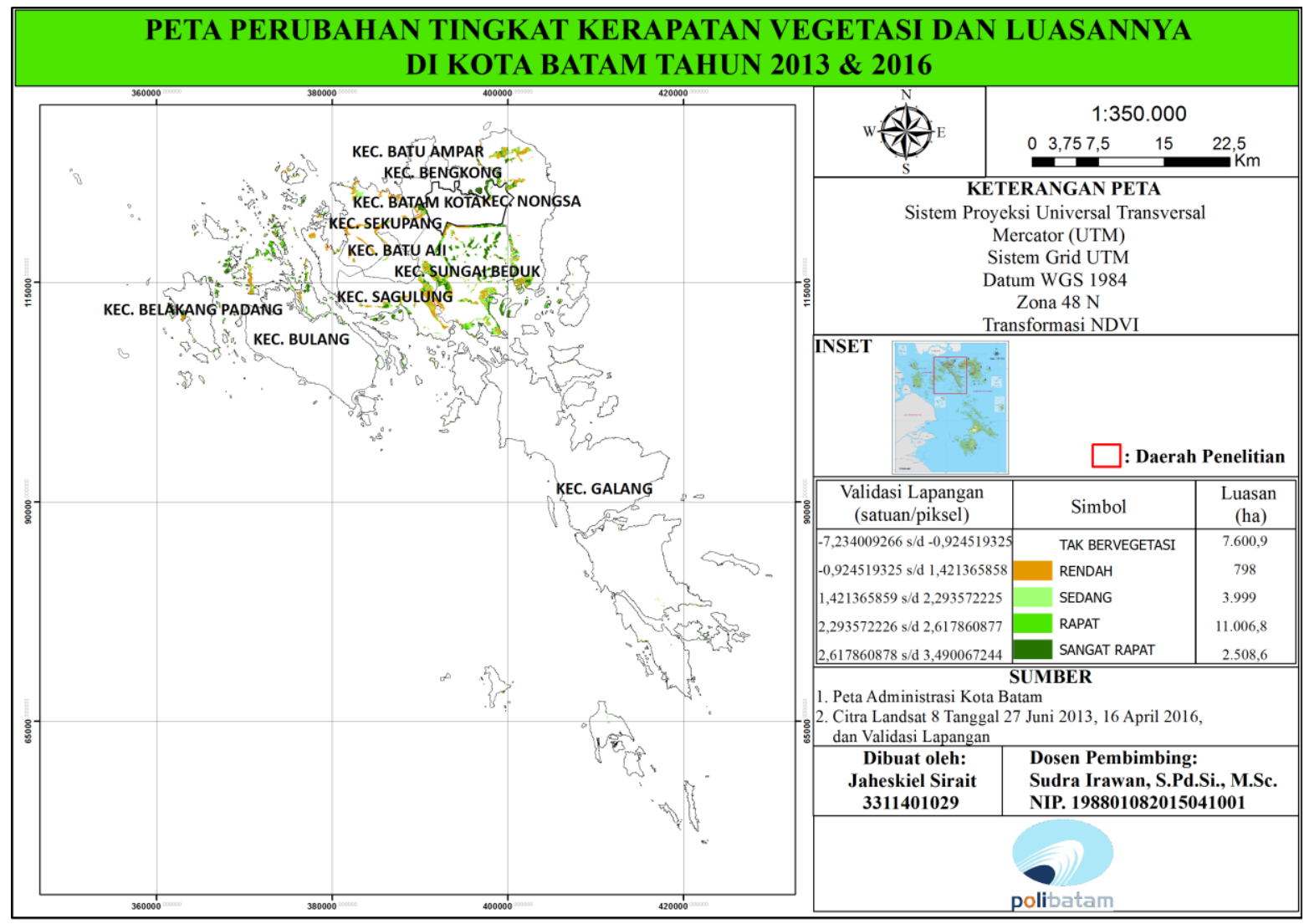

Gambar 5. Peta Perubahan Tingkat Kerapatan Vegetasi dan Luasannya di Kota Batam Tahun 2013 \& 2016

Tabel 3. Perubahan Tingkat Kerapatan Vegetasi dan Luasnya tahun 2013 dan 2016 di Kota Batam

\begin{tabular}{|c|c|c|c|c|c|c|c|}
\hline \multirow{2}{*}{ No } & \multirow{2}{*}{$\begin{array}{l}\text { Tingkat } \\
\text { Kerapatan }\end{array}$} & \multirow{2}{*}{$\begin{array}{c}\text { Pengukuran } \\
\text { Lapangan } \\
\text { (satuan/piksel) }\end{array}$} & \multirow{2}{*}{ Warna } & \multicolumn{2}{|c|}{ Luasannya (ha) } & \multirow{2}{*}{$\begin{array}{l}\text { Perubahan } \\
\text { (ha) }\end{array}$} & \multirow{2}{*}{$\begin{array}{l}\text { Persentase } \\
\text { (\%) }\end{array}$} \\
\hline & & & & 2013 & 2016 & & \\
\hline 1 & $\begin{array}{c}\text { Tak } \\
\text { Bervegetasi }\end{array}$ & $\begin{array}{c}-7,234009266 \text { s.d } \\
-0,924519325\end{array}$ & Putih & $561.701,8$ & $554.100,9$ & $7.600,9$ & 29,3 \\
\hline 2 & Rendah & $\begin{array}{c}-0,924519325 \text { s.d } \\
1,421365858\end{array}$ & Orange & $39.942,9$ & $39.144,9$ & 798 & 3,1 \\
\hline 3 & Sedang & $\begin{array}{c}1,421365859 \text { s.d } \\
2,293572225\end{array}$ & Hijau & $26.317,5$ & $22.318,5$ & 3.999 & 15,4 \\
\hline 4 & Rapat & $\begin{array}{c}2,293572226 \text { s.d } \\
2,617860877\end{array}$ & $\begin{array}{l}\text { Hijau } \\
\text { Muda }\end{array}$ & $24.283,6$ & $13.276,8$ & $11.006,8$ & 42,5 \\
\hline \multirow[t]{2}{*}{5} & $\begin{array}{l}\text { Sangat } \\
\text { Rapat }\end{array}$ & $\begin{array}{c}2,617860878 \text { s.d } \\
3,490067244\end{array}$ & $\begin{array}{l}\text { Hijau } \\
\text { Tua }\end{array}$ & $10.761,4$ & $8.252,8$ & $2.508,6$ & 9,7 \\
\hline & & TOTAL & & $663.007,2$ & $637.093,9$ & $25.913,3$ & 100 \\
\hline
\end{tabular}

Perubahan Kerapatan Vegetasi dan luasannya di Kota Batam tahun 2013 dan 2016 cukup signifikan. Kerapatan Vegetasi yang sangat rapat dari tahun 2013 ke tahun 2016 semakin sedikit terlihat dari hutan, ataupun pepohonan yang ada di Kota Batam mengalami penurunan dikarenakan adanya pertumbuhan penduduk yang membuat pemukiman semakin meningkat. Tingkat kerapatan vegetasi golongan tidak bervegetasi mengalami 
penurunan luas dari tahun 2013 sampai tahun 2016 sebesar 7,600,9 ha. Hal yang sama terjadi pada tingkat kerapatan golongan rendah, sedang, rapat, dan sangat rapat. Besar penurunan luas terjadi pada tingkat kerapatan golongan rapat sebesar $42,5 \%$, disusul tingkat kerapatan tak bervegetasi $(29,3 \%)$, sedang $(15,4 \%)$, sangat rapat $(9,7 \%)$, dan rendah $(3,1 \%)$.

1. Analisis pola keruangan (spatial pattern analysis)

Pada awal tahun 1980 pola ruang yang ada tidak begitu terlihat jelas karena wilayah kota Batam masih belum berkembang pola ruangnya hanya berupa pemukiman yang berada disekitar garis pantai, di wilayah utara pulau Batam dan Barat pulau ini. Selain itu berupa hutan. jadi pola ruangnya berada di sekitar garis pantai. Sedangkan pada saat ini pola ruang cukup terlihat, dapat dilihat pola nnya yaitu pemukiman menyebar di seluruh area, di daerah selatan, utara dan sebagian barat. Mengikuti seluruh jalan yang ada di kota. Tidak terdapat wilayah persawahan, namun yang ada wilayah hutan ditengah pulau ini. Hal ini dapat kita amati pada peta.

2. Analisis struktur keruangan (spatial structure analysis)

Pada tahun 1980, struktur yang ada dalam pemanfaatan lahan adalah hampir $98 \%$ adalah daerah kawasan hutan lebat, dan sisanya pemukiman sekitar pantai. Namun saat ini struktur ruang yang ada hampir $52 \%$ pemamfaatan lahan untuk wilayah terbangun seperti pemukiman dan kawasan industri dan kantor-kantor, sedangkan $48 \%$ lainnya adalah wilayah hutan lindung. Struktur seperti ini merupakan mutlak struktur sebuah kota, hal ini disebabkan kemajuan yang terjadi pada kota ini dari tahun ke tahun.

3. Analisis proses keruangan (spatial process analysis)

Proses yang terjadi sejak awal tahun 1980 , dapat kita lihat pada peta dan kenampakan ynag ada area yang tadinya merupakan hutan lebat dan berbukit-bukit berlahan lahan berubah menjadi lahan terbangun seperti kawasan industri, perumahan, galangan kapal dan sebagainya, perkembangan kota yang sangat cepat mengakibatkan perubahan ruang kota Batam menjadi sangat cepat dalam waktu 30 tahun, kota ini berubah total, setiap saat selalu ada perkembangan di setiap sudut kota ini.
Kondisi vegetasi di Kota Batam pada tahun 1980an hanya ditutupi hutan dengan kondisi fisik tanah yang tidak rata atau bergelombang dan berbukui-bukit dengan keadaan tanah tidak subur karena merupakan tanah bauksit. Ada beberapa analisis perubahan vegetasi di Kota Batam menurut Malindo (2016).

4. Analisis interaksi keruangan (spatial interactiao analysis)

Awalnya interaksi kota Batam dengan wilayah dan kabupaten disekitarnya tidak terlihat intens namun, sejak pembangunan yang intens dilakukan serta penduduk yang semakin meningkat jumlahnya maka terjadi interaksi dengan kawasan/daerah disekitarnya, keberlangsungan kota Batam bergantung pada interaksinya dengan kabupaten sekitar seperti tanjung pinang, Karimun, Natuna,bahkan dengan Sumatra utara dan singapura untuk memenuhi kebutuhan pangan, sandang dan papan penduduknya.

5. Analisis organisasi keruangan (spatial organization analysis)

Batam merupakan golongan dari kota menengah namun keberadaannya seperti kota besar karena mempengaruhi daerah sekitarnya, tidak seperti keadaan awalnya dimana hanya sebagai daerah perbatasan yang tidak potensial, namun saat ini batam menjadi salah satu tonggak perekonomian Indonesia.

6. Analisis asosiasi keruangan (spatial association analysis)

Perubahan asosiasi keruanagan sangat jelas terjadi dari tahun ke tahun, mulai dari hilangnya hutan hingga pengalihan fungsi hutan menjadi wilayah perkotaan dapat kita liha keadaan saat ini pada gambar sangat minim adanya hutan, semua pemukiman dengan jumlah penduduk yang sangat besar, gejala-gejala ini menimbulkan banyak hal negative mulai dari masalah pemukiman kumuh hingga kriminalitas yang tinggi.

7. Analisis Kecenderungan ruang (spatial tendency analysis)

Perubahan ruang yang terjadi dari rentang tahun 1980-2016, terlihat jelas dengan kecenderungan pembangunan kesegalah arah tanpa kecuali hutan lindung dan daerah perbukitan. Pembangunan memang berada pada pusat kota, namun secar umum segala tempat atau area yang ada mengalami pembangunan yang sama. 


\section{Tampilan Web Kerapatan Vegetasi di Kota Batam}

Web digunakan untuk memberikan informasi kepada masyarakat tentang kerapatan vegetasi yang ada di Kota Batam. Tampilan website dapat dilihat pada Gambar 9.

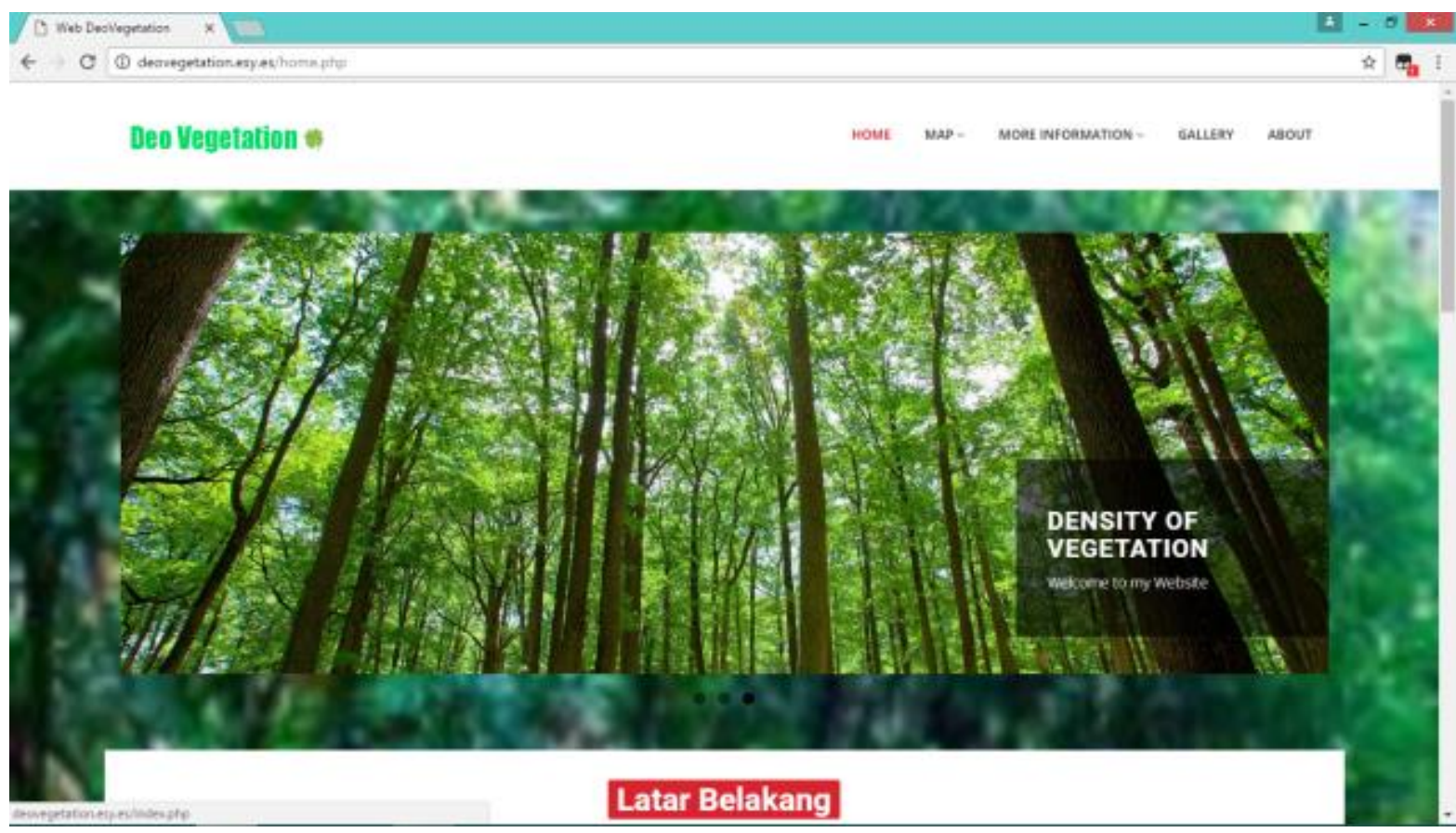

Gambar 6. Web Kerapatan Vegetasi di Kota Batam

Web kerapatan vegetasi di Kota Batam tahun 2013 dan 2016 terdiri dari 5 (lima) menu utama yaitu Home, Map, More Information, Gallery, dan About. Seluruh pengguna internet dapat

Berdasarkan hasil penelitian yang telah dilakukan, maka dapat disimpulkan bahwa:

1. Tingkat kerapatan vegetasi dan luasannya di Kota Batam tahun 2013 yaitu tak bervegetasi mempunyai luas area $561.701,8$ hektar (84,7\%), rendah mempunyai luas area 39.942,9 hektar $(6 \%)$, sedang mempunyai luas area $26.317,5$ hektar $(4 \%)$, rapat mempunyai luas area $24.283,6$ hektar (3,7\%), dan sangat rapat mempunyai luas area $10.761,4$ hektar $(1,6 \%)$.

2. Tingkat kerapatan vegetasi dan luasannya di Kota Batam tahun 2016 yaitu tak bervegetasi mempunyai luas area $554.100,9$ hektar (87\%), rendah mempunyai luas area $39.144,9$ hektar $(6,1 \%)$, sedang mempunyai luas area $22.318,5$ hektar $(3,5 \%)$, rapat mempunyai luas area 13.276,8 hektar (2,1\%), dan sangat rapat mempunyai luas area $8.252,8$ hektar $(1,3 \%)$. menemukan informasi tentang kerapatan vegetasi di Kota Batam tahun 2013 dan 2016 melalui web http://deovegetation.esy.es/.

\section{KESIMPULAN DAN SARAN}

3. Perubahan tingkat kerapatan vegetasi dan luasannya di Kota Batam tahun 2013 dan 2016 cukup signifikan, dengan hutan primer dan hutan sekunder mengalami penurunan disebabkan oleh semakin banyaknya pemukiman di Kota Batam. Perubahan tingkat kerapatan vegetasi dan luasannya di Kota Batam pada tahun 2013 dan 2016 yaitu, tak bervegetasi memiliki perubahan luas area sebesar 7.600,9 hektar $(29,3 \%)$, rendah memiliki perubahan luas area sebesar 798 hektar $(3,1 \%)$, sedang memiliki perubahan luas area sebesar 3.999 hektar $(15,4 \%)$, rapat memiliki perubahan luas area sebesar $11.006,8$ hektar $(42,5 \%)$, dan sangat rapat memiliki perubahan luas area sebesar $2.508,6$ hektar $(9,7 \%)$.

4. Web Perubahan Kerapatan Vegetasi di Kota Batam tahun 2013 dan 2016 memberikan informasi mengenai tingkat kerapatan di Kota Batam yang berbeda di setiap Kecamatan. 


\section{UCAPAN TERIMA KASIH}

Penulis mengucapkan terimakasih kepada BAPELITBANGDA Kota Batam yang telah bersedia memberikan data berupa data shp Administrasi Kota Batam sehingga dapat menunjang dalam pengolahan data untuk peta

\section{DAFTAR PUSTAKA}

Aftriana, C. V. (2013). Analisis Perubahan Kerapatan Vegetasi Kota Semarang Menggunakan Aplikasi Penginderaan JAUH. Geo-Image, 2(2).

Anargi, S. B. (2008). Aplikasi Sistem Informasi Geografis Untuk Pemetaan Perubahan Penggunaan Lahan Kota Semarang Tahun 1994 Dan Tahun 2005. Skripsi. Semarang: UNNES.

Bengen, D. G. (2000). Pedoman teknis pengenalan \& pengelolaan ekosistem mangrove. Pusat Kajian Sumberdaya Pesisir dan Lautan (PKSPL), Institut Pertanian Bogor (IPB), hal 59.

Danoedoro, P. (2012). Pengantar penginderaan jauh digital. Penerbit Andi, Yogyakarta.

Faizal, A., \& Amran, M. A. (2002). Model Transformasi Indeks Vegetasi Yang Efektif untuk Prediksi Kerapatan Mangrove Rhizophora Mucronata. Metode, 114(064).

Irwan, Djamal Z. (2008). Tantangan Lingkungan dan Lasekap Hutan Kota. Cidesindo. Jakarta.

Iskandar, M., Sanjoto, T. B., \& Sutardji, S. (2012). Analisis Kerapatan Vegetasi Menggunakan Teknik Penginderaan Jauh Sebagai Basis Evaluasi Kerusakan Hutan di Taman Nasional Gunung Gede Pangrango. Geo-Image, 1(1).

Kusmana, C. (1993). A Study on Mangrove Forest Management Based on Ecological Data in Eastern Sumatra, Indonesia (Doctoral dissertation, Ph. D. Disertation. Faculty of Agriculture, Kyoto University, Japan. Unpublish). kerapatan vegetasi. Prodi Teknik Geomatika Politeknik Negeri Batam yang menyediakan peralatan untuk alat pengumpulan data dan reviewer yang telah memberikan masukan untuk penyempurnaan tulisan ini.

Nursal, F., Ismiati (2005). Struktur dan komposisi vegetasi mangrove Tanjung Sekodi Kabupaten Bengkalis Riau. Jurnal Biogenesis, 2(1), 1-7.

Riduwan. (2011). Dasar-dasar Statistika. Bandung: Alfabeta.

Suharsimi, A., (2002). Prosedur Penelitian: Suatu Pendekatan Praktek. Jakarta. PT Rineka Cipta.

Spies, T.A., \& M.G. Tunner (1999). Dynamic Forest Mosaic in Monitoring Biodiversity. In Hunter, M.L, Jr. (Ed.). Forest Ecosystem. Cambridge University Press, Cambridge, 8, 35-44.

Sukristiyanti, S., \& Marganingrum, D. (2008). Pendeteksian Kerapatan Vegetasi dan Suhu Permukaan Menggunakan Citra Landsat Studi Kasus: Jawa Barat Bagian Selatan dan Sekitarnya. Jurnal RISET Geologi dan Pertambangan, 19(1), 15-24.

Sunardi Nur. (2009). Pengantar Satistika. Jakarta: Bumi Aksara.

Widayati, A., Ekadinata, A., \& Syam, R. (2005). Alih guna lahan di kabupaten Nunukan: Pendugaan cadangan karbon berdasarkan tipe tutupan lahan dan kerapatan vegetasi pada skala lansekap. Cadangan Karbon Di Kabupaten Nunukan, Kalimantan Timur: Monitoring Secara Spasial Dan Pemodelan. Bogor, Indonesia: World Agroforestry Centre-ICRAF.

Yeni Kustiyahningsih. Dan Devie Rosa Anamisa. (2011). Pemograman Basis Data Berbasis Web Menggunakan PHP \& MySQL. Graha IImu: Yogyakarta. 